\title{
Gas Metal Rapid Arc Welding Potential
}

\section{Zdeněk Hudec}

Faculty of Mechanical Engineering, Department of Engineering Technology, Technical University of Liberec, Studentska 2, 46117 Liberec, Czech Republic, e-mail: zdenek.hudec@tul.cz

The article presents problems with commercial inverter source Rapid Arc application on fillet and V-grooved welds. Principal and conditions of the process are explained and especially restriction due to source and feeder upper power limit is described. Case study of "weld design for fabrication" method was demonstrated, where type of weld and shape of groove is designed on the base of experimental results of process penetration behavior at $1 / 2$ V-groove joint. Results are described and discussed, using special welding parameters monitoring equipment and software. A change of metal transfer behavior was recorded in accordance with torch angle setting and originally explained.

Keywords: GMAW, weld design for fabrication, Rapid Arc, stick-out, melting rate.

\section{Acknowledgement}

This paper was supported by the project of the Technical University of Liberec SGS 2822.

\section{References}

[1] LANCASTER, J, F. (1986). The Physics of Welding, ed. Oxford, Pergamon Press.

[2] WEMAN, K., LINDEN, G. (2006). MIG Welding Guide, ed. By Woodhead Publ., Cambridge.

[3] HUDEC, Z. (2012) GMAW Welds Design for Fabrication of Steel Structures, assoc. prof. degree monograph, Technical University of Liberec, Czech rep.

[4] MYERS, R. H. (1995). Response Surface Methodology, Jo.hn Wiley \& Sons Inc. N.Y.

[5] PIXLEY, M. (1994). Inverter Technology in Welding Power Sources, Welding Review International 13(1).

[6] KOVANDA, K. et al. (2012). Experimental Verification of FEM Simulation of GMAW Bead on Plate Welding. Manufacturing Technology. Vol. 12, No. 6, pp. 30-33.

[7] PODREEZ-RADZISZEWSKA, M. (2011). Weldability problems the Technical AW 7020 Alloy. Manufacturing Technology. Vol. 11, No. 11 pp. 59-66.

[8] CHOTEBORSKY, R., NAVRATILOVA, M. (2011). Experimentalni posouzeni vlivu navarovacich parametru na promiseni navarove housenky. Manufacturing Technology. Vol. 11, No. 10 pp. 44-49.

[9] KOVANDA, K., et al. (2011). Vliv ochrannych plynu pri GMAW svarovani hlinikovych slitin typu EN AW 7022. Manufacturing Technology. Vol. 11, No. 4 pp. 25-32.

[10] KOLARIK, K., et al. (2011). Posouzeni vlivu pridavneho materialu na porovitost svarovych spoju pri MIG svarovani vytvrditelnych hlinikovych slitin typu AlMgSi. Manufacturing Technology. Vol. 11, No. 1 pp. 54-60.

[11] MESKO, J. et al. (2011). Shape of heat source in simulation program SYSWELD using different types of gases and welding methods. Manufacturing Technology. Vol. 11, No. 5 pp. 6-11. 